\title{
LANGUAGE EFFECTIVENESS AND FACTORS INFLUENCING SCIENTIFIC WRITING OF INDONESIAN UNDERGRADUATE THESIS
}

\author{
Saniago Dakhi \\ English Education Department, Faculty of Teacher Training and Education, \\ Universitas Kristen Indonesia \\ Email: saniagonias@gmail.com \\ Horas Hutabarat \\ English Education Department, Faculty of Teacher Training and Education, \\ Universitas Kristen Indonesia \\ Email: anggiat.mananda@yahoo.co.id
}

\begin{abstract}
APA Citation: Dakhi, S., \& Hutabarat, H. (2018). Language effectiveness and factors influencing scientific writing of Indonesian undergraduate thesis. English Review: Journal of English Education, 7(1), 61-74. doi: 10.25134/erjee.v7i1.1496.
\end{abstract}

Abstract: The linguistic feature distinction between written and spoken discourse, like scientific writing, narrative text, discussion text, oral speech, etc. has been a longstanding discussion among scholars. However, there is limited number of studies on Indonesian undergraduate thesis context. This article reports the language effectiveness, i.e. lexical density and grammatical complexity of undergraduate thesis using the Flesch's Analysis of the Readability of Adult Reading Materials (1974) and the determinant factors influencing them. This descriptive study, applying online system application, was conducted in an Indonesian pseudonym university. Forty-two undergraduate theses were used as data source of lexical density and grammatical complexity, and four English lecturers participated on interview. Results showed that the average lexical density ratio was 42.14 and the grammatical complexity was 14.54 . On the other hand, the determinant factors of academic writing holistically encompass; (1) psychological factors including identity awareness, motivation, and conceptual competency, (2) sociocultural factor covering personal experience, and (3) linguistic factors, namely linguistic awareness and application, and mechanical competency. To sum up, three important conclusions are drawn. Firstly, there is no exactly the same lexical density and grammatical complexity across chapters of the undergraduate theses. Secondly, the undergraduate theses are lexically acceptable, but grammatically are not as they are interpreted as American students' slick fiction product. Finally, variables affecting academic writing are not only linguistic factors, but also psychological and sociocultural ones.

Keywords: lexical density; grammatical complexity; undergraduate thesis; Indonesian context; academic writing; language effectiveness.

\section{INTRODUCTION}

Language effectiveness has been a longstanding study among scholars as it is believed that written and spoken discourse, caused by the characteristics and dynamics of living language (Dakhi, 2011), are two different linguistic entities (Halliday, 1989; Zhang, 2013; Ghasemi \& Jahromi, 2014; \& Thanh, 2015). Functionality discrepancies and linguistic features (Ghasemi \& Jahromi, 2014) define their similarity.
The undergraduate thesis, a writing product in which language effectiveness necessitates as it has its own typical features (Pan, 2016), is simply defined as a communicative, efficient, and effective occurrence since textuality standards and grammatical complexity/intricacy, lexical density, nominalization, explicitness, contextualization, spontaneity, and repetition-hesitation and redundancy are met. Additionally, it generally contains a 
generic structure, i.e. introduction (Pardede, 2012). literature review (Levy \& Ellis, 2006), methodology, research finding, discussion, conclusion, and suggestion. Moreover, it requires a complexly-integrated skill (Deane, et al., 2008) as it is a metacognitive process drawing an individual's knowledge, basic skill, strategies, and ability to coordinate multiple processes (Huy, 2015) and expressive, receptive, and reflective capabilities.

A number of empirical studies testify the urgent need of the language effectiveness of undergraduate thesis, a new defined linguists' focus. It, for instance, is evidenced by Stegan (2003) investigating the lexical density in oral and versus written Rangi texts, Seyabi and Tuzlukova (2014) reporting the post-basic school and university students' lexical items and content, Chokwe (2013) researching academic writing skills, and Huy (2015) confirming the student's writing problems, i.e. lexical item and grammar. More specifically, Signes and Arroita (2015), Marques (2008), and Biber, Gray, and Stamples (2016) studied lexical density and investigated grammatical complexity.

In Indonesia, studies on lexical density and grammatical complexity have been only reported by Nesia and Ginting (2018) and Adawiyah (2015). However, Nesia and Ginting (2018) focused their study on the lexical density in English reading texts for Indonesian senior high school, and Adawiyah (2015) differentiated the lexical density in scientific and narrative texts. A study exploring the thesis quality in accordance with written discourse characteristics, therefore, has to be taken into account. The present study is to provide such need. It was designed to objectively describe the lexical density (Halliday, 1985; Flesch, 1974), grammatical complexity (Halliday, 1985; Flesch, 1974) and factors influencing scientific writing (Muchemwa, 2015) of English undergraduate theses of an Indonesian pseudonym private university.

\section{METHOD}

To answer objectively the research questions, 42 undergraduate theses of a pseudonym private university in Indonesia were used as the data source of lexical density and grammatical complexity. The reason for selecting these 42 theses, consisting of 2015 and 2016's undergraduate theses, is because those are the only softcopies of project reports available. In addition, 4 informants participated on an interview, a technique to collect the data regarding the factors affecting undergraduate thesis. The selected four informants were all full-time English lecturers with different time teaching experiences. Their experience teaching English as well as supervising the undergraduate theses were other reasons for the selection of the respondents.

The full texts of undergraduate thesis containing five chapters, namely introduction, literature review, research methodology, research finding and discussion, and conclusion and suggestions, were entirely analyzed using online system application at http://textalyser.net/index.php?lang=en\#anal ysis (for lexical density) offered by the Bernhard Huber Internet Engineering Company and http://www.readabilityformulas.com/freetest s/six-readability-formulas.php (for grammatical complexity). The introduction section is the Chapter I (henceforth $\mathrm{C} 1$ ), the literature review is the Chapter II (henceforth C2), the research methodology is the Chapter III (henceforth C3), the research finding and discussion is the Chapter IV (henceforth C4), and the conclusion and suggestion is the Chapter V (henceforth C5). Scores taken and descriptively analyzed were Mean Length of Sentence (henceforth MLS) for grammatical complexity and Flesch's Reading Ease Score for grammatical one.

Furthermore, both lexical density and grammatical complexity scores were tabulated according to what year, 2015 and 2016, the English undergraduate theses completed. At last, they were interpreted 
ENGLISH REVIEW: Journal of English Education Volume 7, Issue 1, December 2018
p-ISSN 2301-7554, e-ISSN 2541-3643

https://journal.uniku.ac.id/index.php/ERJEE

using Flesch's (1974) Analysis of the related theories.

Readability of Adult Reading Materials and

Table 1. Flesch's analysis of the readability of adult reading materials

\begin{tabular}{|c|c|c|c|c|c|c|}
\hline Style & $\begin{array}{c}\text { Flesch } \\
\text { Reading } \\
\text { Ease } \\
\text { Score }\end{array}$ & $\begin{array}{c}\text { Average } \\
\text { Sentence } \\
\text { Length in } \\
\text { Words }\end{array}$ & $\begin{array}{c}\text { Average } \\
\text { No. of } \\
\text { Syllable } \\
\text { per } 100 \\
\text { Words } \\
\end{array}$ & $\begin{array}{c}\text { Type of } \\
\text { Magazine }\end{array}$ & $\begin{array}{l}\text { Estimate School } \\
\text { Grade Completed }\end{array}$ & $\begin{array}{l}\text { Estimate } \\
\text { Percent of } \\
\text { U.S. adults }\end{array}$ \\
\hline Very Easy & 90 to 100 & 8 or less & $\begin{array}{c}123 \text { or } \\
\text { less }\end{array}$ & Comics & $4^{\text {th }}$ grade & 93 \\
\hline Easy & 80 to 90 & 11 & 131 & Pulp fiction & $5^{\text {th }}$ grade & 91 \\
\hline Fairly Easy & 70 to 80 & 14 & 139 & $\begin{array}{l}\text { Slick } \\
\text { fiction }\end{array}$ & $\begin{array}{l}6^{\text {th }} 6^{\text {th }} \text { or } 8^{\text {th }} \text { grade } \\
\text {. }\end{array}$ & 88 \\
\hline Standard & 60 to 70 & 17 & 147 & Digests & Some high school & 83 \\
\hline $\begin{array}{l}\text { Fairly } \\
\text { Difficult }\end{array}$ & 50 to 60 & 21 & 155 & Quality & High school & 54 \\
\hline Difficult & 30 to 50 & 25 & 167 & Academic & $\begin{array}{l}\text { High school or } \\
\text { some college }\end{array}$ & 33 \\
\hline $\begin{array}{c}\text { Very } \\
\text { Difficult }\end{array}$ & 0 to 30 & 29 or more & $\begin{array}{c}197 \text { or } \\
\text { more }\end{array}$ & Scientific & College & 4.5 \\
\hline
\end{tabular}

An in-depth interview data was analyzed using thematic technique, a process to analyze the classifications and present themes (Alhojailan, 2012) of obtained qualitative data. Three steps were conducted, namely data reduction, data display, and verification/conclusion drawing.

To establish the trustworthiness of the research finding, some techniques were employed. For the lexical density and grammatical complexity, repeated measures on the manuscripts, three times, were conducted to assure dependability of the data. On the other hand, for interview data verification by repeating a similar question to the participants during the interview was conducted. At last, a peer scrutiny of project and member check by the peer review members who were officially assigned has been applied to meet the credibility of the finding.

\section{RESULTS AND DISCUSSION Lexical density}

\begin{tabular}{|c|c|c|c|c|c|}
\hline & $\mathrm{C} 1$ & C2 & $\mathrm{C3}$ & $\mathrm{C} 4$ & C5 \\
\hline Max & 57.20 & 60.00 & 61.50 & 46.70 & 68.20 \\
\hline Min & 44.20 & 33.50 & 32.40 & 21.90 & 40.50 \\
\hline Mean & 51.32 & 43.73 & 39.48 & 26.33 & 53.53 \\
\hline
\end{tabular}

As shown in Table 2, the $\mathrm{C} 1$ mean lexical density of 2015's thesis is 51.32 . This is 7.59 higher than C2's, 43.73 (difficult), 11.48 higher than C3's, 39.48 (difficult), and 24.99 higher than C4's, 26.33 (very difficult). Regardless of that, C5's mean lexical density is the highest one. It is $\mathbf{5 3 . 5 3}$ (fairly difficult) or 2.21 higher than $\mathrm{C} 1$ 's.

Referring to the Flesch's table, specifically to what grade they are interpreted in American student's writing, those 5 units can be categorized into three different groups. The first and fifth chapters are American high school category, meant written by American high school students. The second and third chapters, respectively literature review and research methodology, are estimated as American high school or some college learners' product. Furthermore, the research finding and discussion section is grouped into their college students' writing. This is to say that the literature review, research methodology, and research findings and discussion sections according to genre of Flesch's table are lexically accepted as academic and scientific discourse.

Table 3. Lexical density of 2016's thesis

\begin{tabular}{lccccc}
\hline & C1 & C2 & C3 & C4 & C5 \\
\hline Max & 59.90 & 61.20 & 53.10 & 53.70 & 64.60 \\
Min & 21.30 & 33.30 & 30.30 & 12.20 & 23.40 \\
Mean & 48.03 & 43.75 & 39.55 & 22.70 & 53.01 \\
\hline
\end{tabular}


Though the 2015's and 2016's lexical density are academically acceptable, they show a slight difference. The 2015's lexical density is 42.88 , or 1.47 higher than 2016's (41.14). Moreover, the introduction, literature review, and conclusion and suggestion sections of the 2016's got improved. Hence, this indicates that the 2016's undergraduate theses lexical density got better.

The previous description has made two crucial implications of the findings. They are dealt with the highest and lowest lexical density, and the diversity of lexical density across the writers and undergraduate thesis chapters. It can be stated that both the 2015's and 2016's literature review sections possess the lowest lexical density, the best, and their introduction sections, a piece of discourse which introduces a lengthy discourse, a project report, a laboratory report or even student essay (Stapa, Maasum, \& Aziz, 2014), own the highest ones, the worst.

Thus, this implies twofold. Firstly, regardless of the systematic procedure of literature review (Supriya et al., 2018), theories and previous studies, sources of literature review, primarily predict Indonesian EFL undergraduate's lexical density. It was caused by the fact that the literature synthesis helps the writers develop a knowledge base (Apostolou, Dorminey, Hassell, \& Rebele, 2018) in writing the undergraduate thesis. Secondly, the position of the introduction section at the beginning of the scientific report, presumably reviewed more frequently and intensively, does not affect lexical density.

Finally, the diversity of lexical density indices across the writers and undergraduate thesis chapters obviously approves the dynamics of any living languages (Dakhi, 2016). It means that words have widely varying frequencies of use. Thus, it is natural to have different lexical density across the writers and undergraduate thesis chapters. A similar finding strengthens the nature of that lexical density. Reported by Demir-Vegter, Aarts, and Kurvers (2013), it was claimed that there was also a lexical diversity in maternal input to Turkish preschoolers in the Netherlands.

More importantly, a report by Nesia and Ginting (2018) on lexical density of English reading texts for Indonesian senior high school showed a difference with the present report. They reported that the lexical density of explanative texts were $58.42 \%$ and $52.05 \%$; review texts were $55.73 \%$ and $53.51 \%$; narrative texts were $48.96 \%$ and $43.97 \%$; and discussion texts were $47.79 \%$ and $42.57 \%$.

Discussing the different realization of the lexical density among the data sources is interesting. It is assumed that the difference is mainly caused by genres of the data source. Naturally, academic genre is lexically densed. The data source of the present report was the undergraduate theses, academic genre, while their sources were the English reading texts for senior high school in Indonesia.

An additional report confirming the lexical density of the academic text is Adawiyah (2015). Her/his study was to differentiate lexical density between scientific and narrative texts. It was discovered that the lexical density of scientific texts $(49.4 \%$ and $50.2 \%)$ were higher than the narrative ones $(41.0 \%$ and $40.8 \%$ ).

\section{Grammatical complexity}

Table 4. Grammatical complexity of 2015 's

\begin{tabular}{lccccc}
\multicolumn{7}{c}{ thesis } \\
\hline & C1 & C2 & C3 & C4 & C5 \\
\hline Max & 18.72 & 20.32 & 16.88 & 16.45 & 17.05 \\
Min & 13.25 & 11.51 & 9.47 & 8.00 & 10.21 \\
Mean & 15.93 & 15.58 & 12.89 & 11.75 & 14.64 \\
\hline
\end{tabular}

As shown in Table 4 that the mean MLS index of the $\mathrm{C} 1$ of the 2015's thesis is 15.93 (fairly easy), received the most grammatical complexity. Respectively, C2, C5, C3, and $\mathrm{C} 4$ are 15.58 (fairly easy), 14.64 (fairly easy), 12.89 (easy), and 11.75 (fairly easy), the least grammatical complexity. The data implies that, firstly, grammatical complexity of the chapter of the 2015's English undergraduate theses is standard, fairly difficult, difficult, and very difficult category. 
ENGLISH REVIEW: Journal of English Education Volume 7, Issue 1, December 2018

Secondly, the MLSes of C1, C2, and C5 are categorized as fairly easy, and the MLSes of $\mathrm{C} 3$ and $\mathrm{C} 4$ are easy. Consulting the Flesch's table, therefore, the introduction, literature review, and conclusion and suggestion sections of the 2015's equal to the 6th-8th American graders' writing.

On the other hand, the MLSes of the 2016's English undergraduate theses are displayed in Table 5. It shows that the MLSes of $\mathrm{C} 1, \mathrm{C} 5, \mathrm{C} 2, \mathrm{C} 4$, and $\mathrm{C} 3$ are respectively 16.86 (fairly easy), 16.45 (fairly easy), 16.06 (fairly easy), 12.64 (easy), and 12.56 (easy). It means the introduction section, educational writing genre (Kawase, 2015) received the most grammatical complexity, and the methodology section was the least one.

Table 5. Grammatical complexity of 2016's

\begin{tabular}{llllrl}
\multicolumn{6}{c}{ thesis } \\
\hline & C1 & C2 & C3 & \multicolumn{1}{c}{ C4 } & C5 \\
\hline Max & 20.36 & 20.11 & 16.45 & 19.23 & 19.82 \\
Min & 13.68 & 13.34 & 8.66 & 7.01 & 11.65 \\
Mean & 16.86 & 16.06 & 12.58 & 12.64 & 16.45 \\
\hline
\end{tabular}

The average MLS of C1, C2, C3, C4, and C5 of both 2015 and 2016's MLS is respectively 16.40 (fairly easy), 15.82 (fairly easy), 12.74 (easy), 12.20 (easy), and 15.55 (fairly easy). Comparing the MLSes of both 2015 and 2016's English undergraduate theses suggests some important implications. Firstly, both the introduction sections of 2015 and 2016's theses had the highest grammatical complexity. Secondly, the entire MLS of 2016's undergraduate theses, except C3, are greater than those of 2015's, statistically evidenced by the deviated mean MLS of 2015 (14.16) and 2016's (14.92) theses, 0.76. Thirdly, such finding syntactically testifies the graduate's English writing growth.

Though the current study did not focus on reasons for the grammatical complexity growth in 2016's English undergraduate theses, it is obvious that sentence length is a robust measure of sentence structure (Vieira, Picoli, \& Mendes, 2018). This means that the growth of the MLS predicts undergraduate's improved writing. Furthermore, such MLS growth confirms
p-ISSN 2301-7554, e-ISSN 2541-3643

https://journal.uniku.ac.id/index.php/ERJEE

that language is basically systematic and learnable (Dakhi, 2016).

Additional factor making the finding reasonable is learners' cognitive diversity. Obviously, students have different abilities. In this regard, it is normal that MLSes of 2015 and 2016's graduates' writing ability are different. Some similar findings showing the learners' different skill. Muslim (2014) reports that EFL students' writing ability was significantly different and Bauerly and Gottwald (2009) find that the complexity level of fluent and stuttered utterances produced by children was significantly different exemplify it.

However, the grammatical complexity growth of the 2016's theses did not meet MLS standard of academic discourse. Consulting Table 1, the 2016's undergraduate theses are identical to the 6th graders of American products. Therefore, this strengthens Pan's claim (2016) that academic writing is grammatically complex. Similar evidence of the complexity of the writing was reported by Javed, $\mathrm{Wu}$, and Nazli (2013) that the overall performance of all their research respondents was better in comprehension as compared to other subskills, namely word completion, sentence making/syntax, tenses/grammar, and handwriting. In a different context, Ling and Ling (2008) confirmed the writing complexity by arguing that international students in a Canadian university passed TWE (Test of Written English) after repeatedly doing it.

\section{Relating lexical density and grammatical complexity}

Relating the lexical density and grammatical complexity shows the 2015's language effectiveness of undergraduate thesis, i.e. lexical density (42.88) and grammatical complexity (14.16) and the 2016's i.e. lexical density (41.41) and (14.92). The 2015's lexical density consulted with Flesch's theory shows that they are fairly difficult and are estimated written by some American high school students. On the other hand, its MLS index (14.16) is fairly easy, 


\section{Saniago Dakhi \& Horas Hutabarat}

Language effectiveness and factors influencing scientific writing of Indonesian undergraduate thesis

produced by the sixth American graders. The 2016's lexical density is difficult and estimated written by high school or some college American students, and its MLS index is identical to the 2015's. Averagely, the lexical density is 42.14 and grammatical density is 14.54. Interestingly, lexical density interpreted as a high school or some college of American student's product, deviating the MLS, is a sixth American grader's product.

One of the reasons what MLS makes low is what Saaristo (2015) reported. He argued grammar understood as a metalinguistic set of (also normative) statements of regularities in language, which is the way most students think of grammar, results in the bad grammatical complexity of the undergraduate thesis. This is due to the fact that in writing process, grammar is obliged to be a skill, that is something that we have to do and practice, not a knowledge. However, some techniques to improve the MLS, though it lowers the lexical density, is the use of direct speech, frequent use of opening and closing devices, of connectives, of copula and of pronouns (Stegan, 2003).

Conversely, an effective way to improve lexical density is through vocabulary mastery. Regardless of L2 lexical density proficiency has a differential impact on EFL learners' summary writing (Baba, 2009), lexical items still hold a crucial role in language proficiency. It is because vocabulary is a basis for communicating either in verbal or nonverbal forms. Referring to this, meeting the received lexical density requires lexical sophistication, diversity, and richness.

\section{Factors influencing language effectiveness \\ Identity awareness}

It was reported personal consciousness and awareness as English lecturers, professional identity, led to a complete comprehension of some academic efforts developing teaching skills, particularly language skills, language teaching, and ICT. The academic activities, the action, including conducting research, attending scientific seminars, workshops, and conferences, reading, and designing teaching equipment make the lecturers' responsibilities concrete. A similar research finding reported that the participants, in the process of gaining self-awareness and selfknowledge, experienced themselves as approaching professional situations in new ways, gained theories and methods, which they consider as useful in understanding their every-day professional practices and showed a change in their experience of "who they are" as professionals. This, defining the role of identity awareness in a workplace, can be seen in the themes "awareness of personal resonance", "awareness personal point of reference", and in "situational awareness," (Andrén, 2012).

Importance of self-awareness in learning has been a longstanding study. Oscarson (2009) discovered both teachers and students considered student self-assessments as contributing valuable additional information to ordinary tutoring and testing. Ghamari and Khatib (2011) reported that there was a mutual and dynamic relationship between identity and language learning. Furthermore, in chemistry teaching, Alkan and Erdem (2014) also confirmed that there was relationship between metacognitive awareness, competency perception, and teacher self-efficacy.

Oyserman, Elmore, and Smith (2012) stated identities are the traits and characteristics, social relations, roles, and social group memberships. In this regard, the personal identity awareness and profession as English lecturer, playing a central role, define the roles, consequently determine the efforts saving the lecturer's face.

The core definition of identity, furthermore, is manifested into three main domains. It consists of the past-what used to be true of one, the present-what is true of one now, or the future-the person one expects or wishes to become, the person one feels obligated to try to become, or the person one fears one may become. The past refers to EFL learners' learning quality from which they acquire the true knowledge. The 
ENGLISH REVIEW: Journal of English Education Volume 7, Issue 1, December 2018

present is concerned with students' current efforts in EFL learning either in classrooms or at home. Finally, the future is defined as the EFL learners' dreams and expectations.

\section{Personal experience}

No denies that experience as the best teacher; therefore is a final and validated truth shared to any individuals' frame of reference. In learning language context, more specifically writing, experience is viewed as a schemata. The schemata is a pre-existing knowledge of the world, a collection of a concept including background knowledge of content, text structure, and hierarchical organization of the text (Fushan, 2014).

The schemata is enormously useful in EFL learning. There have been many scientific studies testifying it. According to Ferdipour and Delavar (2011) the schemata, parts of macrostructure of text, have a significant effect on written communication. Still about the schemata, Radzi and Aziz (2014) discovered that content schemata had influenced the learners' text comprehension.

On EFL teaching, conversely, the experience deals with teaching experience. EFL teachers' various experiences hold a key role in influencing EFL learners' behavior. Thus, an account for types of experience and teacher professionalism is interesting since different teachers have different experiences and then different orientations in teaching. Reported by Louws, Meirink, Veen, and van Driel (2017), an evidence of different experiences resulting in different teaching orientations, early- and late-career teachers showed greater preference to learn about classroom management compared to mid-career.

However, only insightful and useful teaching is needed to accomplish EFL learning objectives. The insightful and useful teaching experiences are products of reflective thinking. Supported by Afshar and Farahani (2015), they claimed there was a significant positive correlation between reflective teaching and reflective thinking. It indicates that the insightful and useful EFL
p-ISSN 2301-7554, e-ISSN 2541-3643

https://journal.uniku.ac.id/index.php/ERJEE

teaching experience are positively obtained through teachers' reflective thinking.

According to the present study, attractiveness, revision, feasibility, and practicality of literacy skills result in the teaching and learning interest, consequently becoming stored into a longterm memory forming the teaching English writing. Some related studies support such findings. The attractiveness predicted well-being and social connectiveness (Plaut, Adams \& Anderson, 2009); subsequently influenced the great physical and psychological health, student-student interaction and studentteacher interaction.

Views on revision or reversibility role in writing have, although, changed dramatically over the last two decades, revision and its strategies still hold a vital role in writing process. This is in line with Woo, Chu, and Li's (2013) argument that peer-feedback sheds light on influence of peer-feedback, one of the strategies of revision, on the writing process. Automated writing evaluation (AWE), another strategy on revision, is helpful for ESL writers to improve linguistic accuracy (Li, Link, \& Hegelheimer, 2015). However, an account for reviewer and peer-feedback provider has to be considered as only experienced writers can do it. Reported by Calkin (2018), it was explained since the writing is an inner behavior, only the writer could observe and review it.

Moreover, feasibility study on language learning, a procedure to predict outcome of an investigation examination, or assessment of a planned schema along with possible gain (Mukherjee \& Roy, 2017), holds an important role in deciding whether there is possibility to achieve the learning outcomes. Study on the importance of feasibility studies has been conducted by Wuest et al. (2015) and by Organisation for Economic Co-operation and Development or OECD (2013) reminding that feasibility is not an end in itself, but rather a stimulus to deeper professional dialogue on desired learning outcomes and the teaching approaches needed to achieve them. Learning feasibility 


\section{Saniago Dakhi \& Horas Hutabarat}

Language effectiveness and factors influencing scientific writing of Indonesian undergraduate thesis

adopted from Mukherjee and Roy (2017) comprises technical, economic, legal, and operational feasibility.

Finally, practicality is assumed as a determinant factor of the well-planned execution of writing project in EFL context. Pouliot (2008) explored three dimensions of practicality: instrumental rationality (logic of consequences), norm-following (logic of appropriateness), and communicative action (logic of arguing).

\section{Motivation}

It is believed something getting done is highly influenced by the degree of the needs possibly met (Maslow, 1954), a psychological factor (Dwihandini, Marhaeni, \& Suamajaya, 2013). Rasekh and Barati (2014) confirmed that motivation contributes to the learning environment, teachers, techniques, and the material. According to Dakhi and Damanik (2018) curiosity $(92.22 \%)$, challenge (83\%), compliance (77.67\%), competition in reading (77.50\%), reading importance $(73.33 \%)$, reading involvement $(72.50 \%), \quad$ recognition $(68.33 \%)$, reading for grades $(67.08 \%)$, reading efficacy $(59.44 \%)$, avoidance (59.17), and social reason (55.56) are motivation variables of tenth graders at SMA Negeri 55, Jakarta.

Another factor making someone motivated to do something is feedback. Feedback provision through teaching, a need for improving the hard skill and pedagogic skill, motivates the teacher of English writing. The feedback is viewed as an information provided by an agent (e.g., teacher, peer, book, parent, experience) regarding aspects of one's performance or understanding. Although feedback has a powerful influence on learning and achievement, its type produces different output (Hattie \& Timperley, 2007). Three factors predict an evaluative feedback, tested by Azzam and Whyte (2018), are delivery strategy, accuracy, and type (positive/negative).

Therefore, strategy on how to provide the feedback has to be taken into account by
English teachers. One of the strategies enhancing the feedback quality is by applying a web application, the Minute Feedback System (MFS). Barrett, et al. (2018) reported that about $98.6 \%$ of students (138 women, 140 men) used MFS. They asked the feedback more from faculty (26.3 requests per individual) compared to trainees (16.4 requests per individual).

On the contrary, a responsibility being a lecturer and of course learner, the duty, has driven the teaching writing. It is viewed as a bundle of obligations associated with a job or function, like teacher and leaner of writing teaching, as narrowly defined as a role, job description, by which function is described. As Francis (2012) stated teachers have the charge to set environmental conditions for the learner, the teacher is the key external component, collaborating with the student to encourage, cultivating and drawing out the student's motivation to learn, the responsibility is clearly defined. Thus, teaching and learning writing is a social responsibility (Sihem, 2013).

Furthermore, teaching boredom, another motivation variable, on the other hand, puts an action on the meaningless and unattractive struggle of process of a possible background of the undergraduate thesis lexical density and grammatical complexity. Though boredom is defined as an interrelated and inseparable emotional, motivational, perceptual and cognitive concomitants, it serves to encourage people to seek new goals and experiences and provides a valuable adaptive function by signalling its time to pursue a goal of a writing project (Bench \& Lench, 2013). Lastly, an experience, problem-solving, and role model to be an objective examiner have totally met the needs in teaching and learning writing.

According to the present study, it revealed, surprisingly, no negative external motivation implying the threat absence as the positive external is practiced, but positive internal and negative internal ones exist. The feedback provision, responsibility, duty, loyalty, and good team-work function 
ENGLISH REVIEW: Journal of English Education Volume 7, Issue 1, December 2018

as the positive external motivation, and experience, role model and objective examiner are treated as positive internal motivation through which positive motivation dominates over the negative one. Moreover, the boredom, e.g. meaningless and unattractive teaching and learning academic writing meets the negative internal motivation.

\section{Linguistic awareness and application}

Any living languages have vocabulary and system of structure, a theoretical background language learnability claim as learning by system has made teaching possible, a basic element of language teaching and language production. Linguistic awareness consists in the mental recognition, a state of knowing the cultural features of both spoken and written discourse hidden in linguistic manifestation, the acceptable application and its mutual connection with the other studies.

Ideally, a good theoretical concept understanding is definitely appropriately interpreted into an acceptably correct application, i.e. spoken and written discourse linguistic features differ. Consequently "learning language" and "learning about the language" are obviously traced for which grammar as skill application in the scientific undergraduate thesis, not as science, is entirely executed. Mahadouche (2010) confirms writing awareness difficulty contributes on the writing skill supports the urgency of linguistic awareness and application to some extent and strengthens linguistic proficiency as a dominant factor on the students' research report (Dwihandini, Marhaeni, \& Suamajaya, 2013).

\section{Conceptual and mechanical competence}

A conceptual competence requiring a creativity to conceive ideas and transmute them into an observably physical object (Egiri \& Wuritka, 2016) is highly identical to the very beginning process of language production ability including writing as it precedes the formulation, articulation, and self-monitoring phase. A syntactic thinking
p-ISSN 2301-7554, e-ISSN 2541-3643

https://journal.uniku.ac.id/index.php/ERJEE

process of language production, a nonsyntactic or imaginary one definitely proceeds a logical and socially acceptable idea with formal form according to the frame of social reference. Human language conceptualization, some are universal and others are language-specific, is defined in different physical and cultural environments. Even though language conceptualization is complex since content selection, syntactic form selection, and sound sequences are human problem, a study on how to conceptualize and communicate conducted through the use of drawing evidence that language conceptualization can be trained. In this study, mastering the topic and research methodology defines conceptual competence. A holistic view on the topic of the writing puts the writer on the right access to the writing success, and research methodology frames the nature of the question and establish a path along which research (Jonker \& Pennik, 2010) and its report can be directed. Competency in choosing the topic is required as it functions to establish a well-defined task environment dimension of the writing, a process-based approach to writing (Bayat, 2014). On the contrary, the mechanics and coherence application to the writing completes the mechanical variables. An emphasis on perceived grammar, spelling, and usage including mechanics and coherence application is product-based. The product approach to writing according to Palpanada, Salam, and Ismail (2014) completely encompasses familiarization, controlled writing, guided writing, and free writing.

Regarding the previous research finding and discussion, some implications are provided as follows:

a. The distinction of lexical density and grammatical complexity index of undergraduate thesis according to its unit of chapter and time written confirms the writing skill improvement, the dynamics of language, an altered output driven by the context of the writing purpose and strengthens the writing as a complex integrated skill. 
b. The lexical density interpretation, a high school or some college of American student's product, deviates the MLS, a sixth American grader's product. Ideally, MLS index is not an obstacle increasing the syntactic complexity since in this study grammatical complexity is merely an average word length in sentence, a non-structurally and semanticallysentence-based index. An unrecognized characteristic of English language sentence by the undergraduates, therefore, is obviously captured.

c. Although the fifth chapter is the core unit of the research report providing the scientific answer of the problem and is presumably frequently revised and reviewed by thesis advisors, it is lexically the most ineffective part compared to the others since. This is to confirm a negative attitude on research finding and to predict a mental boredom of the writer.

d. Elaborating motivation of teaching and learning English writing, the feedback provision, responsibility, duty, loyalty, and good team-work function as the positive external motivation, and experience, role model and objective examiner are treated as positive internal motivation through which positive motivation dominates over the negative one. Moreover, the boredom, e.g. meaningless and unattractive teaching and learning academic writing meets the negative internal motivation. This surprisingly shows that no negative external motivation practiced, a threat.

e. Regardless of the low grammatical complexity index, conceptual and mechanical competency as a determinant factor of the writing success, an integration of process and product-based writing approach is the finest model.

\section{CONCLUSION}

Three important conclusions are drawn in this scientific study. Firstly, the diversity of lexical density realization in the undergraduate thesis according to its unit of chapter and time composed is averagely 42.14, to some extent, it is acceptable as an American student's academic product. Secondly, the writing quality improvement assessed through grammatical complexity, 2015's MLS index is 14.16 and 2016's MLS score is 14.92 , still defines its syntactical complexity mean index, 14.54, as slick fiction product of the sixth American students. Finally, determinant factor of academic writing holistically encompasses psychological factors, i.e. identity awareness, motivation, and conceptual competency, sociocultural factor, i.e. personal experience, and linguistic factors: linguistic awareness and application and mechanical competency.

To acquire a sustainable research project and improve linguistically academic acceptance of the undergraduate thesis, more generally English writing, some suggestions and recommendations are listed:

1) The tolerated index of undergraduate thesis lexical density does not guarantee the academic and technical content as this research employed a calculation on-line system; thus, for its pure acceptance, it has to be further studied through semantic-based analysis.

2) Since the research interpretation was consulted with the Flesch's theory, an Indonesian language text readability index is an urgently needed for linguists' research.

3) The lexical density index decrease and the grammatical complexity increase have to be seriously taken into account by English lecturers and students of pseudonym university. A well-defined, planned, and conducted both process and product-based approach to writing are the appropriately finest model. A detailed concept and well-trained writing syntactically constructing a practical, academic and scientific thesis product are advisedly to be executed.

\section{ACKNOWLEDGEMENT}

This research was entirely funded by the English Education Department (EED), 
ENGLISH REVIEW: Journal of English Education Volume 7, Issue 1, December 2018

Faculty of Teacher Training and Education, Universitas Kristen Indonesia (UKI) in 2017.

\section{REFERENCES}

Adawiyah, R. (2015). Grammatical intricacy and lexical density in scientific and narrative texts. (Undergraduate Thesis). Medan: Universitas Sumatera Utara. Retrieved from http://repository.usu.ac.id/bitstream/handle/1234 56789/62923/Cover.pdf?sequence=7.

Afshar, H. S., \& Farahani, M. (2015). Reflective thinking and reflective teaching among Iranian EFL teachers: Do gender and teaching experience make a difference? Procedia-Social and behavioral sciences, 192, 615-620. doi: 10.1016/j.sbspro.2015.06.107.

Alkan, F., \& Erdem, E. (2014). The relationship between metacognitive awareness, teacher selfefficacy, and chemistry competency. ProcediaSocial and Behavioral Sciences, 778-783. doi: 10.1016/j.sbspro.2014.07.475.

Alhojailan, M. I. (2012). Thematic analysis: A critical review of its process and evaluation. West east journal of social sciences, 1 (1), 39-47. Retrieved from

https://fac.ksu.edu.sa/sites/default/files/ta_themat ic_analysis_dr_mohammed_alhojailan.pdf.

Andrén, U. (2012). Self-awareness and selfknowledge in professions: Something we are or skill we learn. Göteborg: Acta Universitatis Hothoburgenesis.

Azzam, T., \& Whyte, C. E. (2018). Evaluative feedback delivery and the factors that affect success. Evaluation and program planning, 67, 148-159. 10.1016/j.evalprogplan.2017.11.005.

Apostolou, B., Dorminey, J. W., Hassell, J. M., \& Rebele, J. E. (2018). Accounting education literature review (2017). Journal of accounting education, 43, 1-23. doi: 10.1016/j.jaccedu.2018.02.001.

Baba, K. (2009). Aspects of lexical proficiency in writing summaries in a foreign language. Journal of second language writing, 18(3), 191-208. doi: 10.1016/j.jslw.2009.05.003.

Bauerly, K. R., \& Gottwald, S. R. (2009). The dynamic relationship of sentence complexity, childhood stuttering, and grammatical development. Contemporary Issues in Communication Science and Disorders, 36, 1425.

Bayat, N. (2014). The effect of the process writing approach on writing success and anxiety. Educational Sciences: Theory and Practice, XIV(3), 1133-1141. doi: 10.12738/estp.2014.3.1720.

Bench, S. W., \& Lench, H. C. (2013). On the function of boredom. Behavioral Sciences, III, 459-472. doi: 10.3390/bs3030459.
p-ISSN 2301-7554, e-ISSN 2541-3643

https://journal.uniku.ac.id/index.php/ERJEE

Biber, D., Gray, B., \& Stamples, S. (2016). Contrasting the grammatical complexities of conversation and academic writing: Implication for EAP writing development and teaching. Language in Focus Journal, 2(1).

Calkin, A. B. (2018). Writing on writing. International journal of educational research, 87, 127-137. doi: 10.1016/j.ijer.2017.05.002.

Chokwe, J. M. (2013). Impacting academic writing skills of English second language students. Mediterranean Journal of Social Science, IV(14), 337-384.

Dakhi, S., \& Damanik, I. S. (2018). Students' motivation in reading English text: A qualitative study in EFL context. Journal of English teaching, 4(2), 81-93. Retrieved from http://ejournal.uki.ac.id/index.php/jet/article/view 1832.

Dakhi, S. (2016). Foreign language acquisition of souvenir seller in Bawomataluo village. Journal Ilmu Bahasa, II(1), 16-32. doi: 10.22225/jr.2.1.46.16-32.

Dakhi, S. (2011). Lexical changes of southern dialect of Li Niha (Master Thesis). Medan: Universitas Negeri Medan. Retrieved from http://digilib.unimed.ac.id/3219/.

Deane, P., et al. (2008). Cognitive models of writing: Writing proficiency as a complexly integrated skill. Princeton: Educational Testing Service.

Demir-Vegter, S., Aarts, R., \& Kurvers, J. (2013). Lexical richness in maternal input and vocabulary development of Turkish preschoolers in the Netherlands. Journal of psycholinguistic research, 43(2), 149-165. doi: 10.1007/s10936013-9245-7.

Dwihandini, L. A., Marhaeni, A. A. I. N., Suamajaya, I. W. (2013). The analysis of the factors affecting undergraduate students' difficulties in writing thesis in the English Department of Mahasaraswati University. E-journal Program Pascasarjana Universitas Pendidikan Ganesha, II, 1-12. Retrieved from https://media.neliti.com/media/publications/2069 45-the-analysis-of-the-factors-affecting-un.pdf.

Egiri, Y. O., \& Wuritka, E. (2016). Conceptualizing concepts: A new approach to industrial design. doi: 10.13140/RG.2.2.23092.45443

Ferdipour, A., \& Delavar, A. (2011). The effect of rhetorical patterns or schemata on reading comprehension in expository text of Perian. Procedia-Social and behavioral sciences, 30, 690-693. doi: 10.1016/j.sbspro.2011.10.133.

Flesch, R. (1974). The art of readable writing. New York: Harper.

Francis, J. M. (2012). Student-regulated learning: Roles and responsibilities for students motivation (Master Thesis). West Point: United States Military Academy. Retrieved from https://www.usma.edu/cfe/Literature/Francis_12. pdf. 


\section{Saniago Dakhi \& Horas Hutabarat}

Language effectiveness and factors influencing scientific writing of Indonesian undergraduate thesis

Fushan, S. (2014).The application of schema theory in teaching college English college writing. Theory and Practice in Language Studies, IV( 7), 1476-1482. doi: 10.4304/tpls.4.7.1476-1482.

Ghamari, A. M., \& Khatib, M. (2011). Mutual relations of identity and foreign language learning: An overview of linguistic and sociolinguistic approaches to identity. Theory and Practice in Language Studies, I(12), 17011708. doi: 10.4304/tpls.1.12.1701-1708.

Ghasemi, H., \& Jahromi, M. K. (2014). The difference between spoken and written discourse in English. International Journal of Language Learning and Applied Linguistics World, VI(4), 147-155.

Halliday, M. A. (1989). Spoken and written language. Oxford: Oxford University Press.

Huy, N. T. (2015). Problems affecting learning writing skill of grade 11 at Thong Linh High School. Asian Journal of Educational Research, II(2), 53-69.

Javed, M., Wu, X. J., \& Nazli, S. (2013). A study of students' assessment in writing skills of the English. International Journal of Instruction, VI(2), 129-144. Retrieved from https://files.eric.ed.gov/fulltext/EJ1085369.pdf.

Jonker, J., \& Pennik, B. (2010). The essence of research methodology. doi: 10.1007/978-3-54071659-4_2.

Kawase, T. (2015). Metadiscourse in the introductions of $\mathrm{PhD}$ theses and research articles. Journal of English for academic purposes, 20, 114-124. doi: 10.1016/j.jeap.2015.08.006.

Levy, Y., \& Ellis, T. J. (2006). A system approach to conducting an effective literature review in support of information system research. Informing Science Journal, IX, 181-212.

Li, J., Link, S., \& Hegelheimer, V. (2015). Rethinking the role of automated writing evaluation (AWE) feedback in ESL writing instruction. Journal of second language teaching, 27, 1-18. doi: 10.1016/j.jslw.2014.10.004.

Ling, H., \& Ling, S. (2008). ESL students' perceptions and experiences of standardized English writing tests. Assessing Writing, XIII(2), 130-149. doi: 10.1016/j.asw.2008.08.001.

Louws, M. L., Meirink, J. A., van Veen, K., \& van Driel, J. H. (2017). Teacher's self-directed learning and teaching experience: What, how, and why teachers want to learn. Teaching and teacher education, 66, 171-183. doi: 10.1016/j.tate.2017.04.004.

Mahadouche, M. (2010). Developing the writing skill through increasing learners' awareness of the writing process: The case of second-year Students-University of Constative (Master Thesis). Retrieved from https://bu.umc.edu.dz/theses/anglais/HAM1132.p df.
Marques, G. (2008). Establishing a continuum in spoken and written language in student emails. Odense Working Papers in Language and Communication (pp. 564-576).

Maslow, A. (1954). Motivation and personality. New York: Harper and Bros.

Muchemwa, S. (2015). factors influencing the learning of English language for academic purposes for foreign students: A case of Solusi University. European Online Journal and Social Sciences, IV(3), 527-533.

Mukherjee, M., \& Roy, S. (2017). Feasibility studies and important aspect of project management. International Journal of Advanced Engineering and Management, II(4), 98-100. Retrieved from https://ijoaem.org/00204-25.

Muslim, I. M. (2014). Helping EFL students improve their writing. International Journal of Humanities and Social Studies, IV(2), 205-12. Retrieved from https://pdfs.semanticscholar.org/8650/5e5674fefa a9b63af0dd76405985c77db95c.pdf.

Nesia, H. B., \& Ginting, S. A. (2018). Lexical density of English reading texts for senior high school. Retrieved from https://media.neliti.com/media/publications/2219 25-none.pdf.

Organization for Economic Co-operation and Development. (2013). Assessment of higher education learning outcomes feasibility study report. Retrieved from http://www.oecd.org/education/skills-beyondschool/AHELO\%20FS\%20Report\%20Volume\% 201\%20Executive\%20Summary.pdf.

Oscarson, A. D. (2009). Self-assessment of writing in learning English as a foreign language: A study at the upper secondary school level. Göteborg: GesonHylteTryck. Retrieved from https://files.eric.ed.gov/fulltext/ED505960.pdf.

Oyserman, D., Elmore, K., \& Smith, G. (2012). Self, self-concept, and identity. In M. R. Leary, \& J. P.Tangney, The Handbook of Self and Identity (pp. 69-104). New York: The Guilford Press.

Palpanada, S. T., Salam, A. R. B., \& Ismail, F. B. (2014). Comparative analysis of process versus product approach of teaching writing in Malaysian schools: Review literature. MiddleEast Journal of Scientific Research, XXII(6), 789-795.

doi: 10.5829/idosi.mejsr.2014.22.06.21943.

Pardede, P. (2012). Scientific articles structure. Scientific Writing Workshop. Retrieved from https://drive.google.com/file/d/0B7pJkzTapTsOU 0NuSVBBT3lzc28/edit.

Plaut, V. C., Adams, G., \& Anderson, S. L. (2009). Does attractiveness buy business? "It depends on where you are from". Journal of the International Association for Relationship Research, XVI, 619630.

Retrieved from 
ENGLISH REVIEW: Journal of English Education Volume 7, Issue 1, December 2018

https://www.law.berkeley.edu/files/Attractivenes s_paper.pdf.

Pouliot, V. (2008). The logic of practicality: A theory of practice of security communities. International Organization, 62(2), 257-288. doi: 10.1017/S0020818308080090.

Radzi, A. H. M., \& Aziz, N. H. A. (2014). Exploring content schemata influence on L2 learners' comprehension of Zuraidah Omar's. Twelve and not stupid. Procedia - Social and behavioral sciences, $\quad 155, \quad 215-222 . \quad$ doi: 10.1016/j.sbspro.2014.10.282.

Rasekh, A. S., \& Barati, H. (2014). Teachers' feedback and students' motivation in English for general and specific purposes courses in Iran. Theory and Practice in Language Studies, V(5), 973-981. doi: 10.4304/tpls.4.5.973-981.

Saaristo, P. (2015). Grammar is the heart of language: grammar and its role in language learning among Finnish university students. In J. Jalkanen, E. Jokinen, \& P. Taalas (Eds.), Voices of pedagogical development - Expanding, enhancing and exploring higher education language learning (pp. 279-318). Dublin: Research- publishing.net. doi: 10.14705/rpnet.2015.000296.

Seyabi, F. A., \& Tuzlukova, V. (2014). The writing problem and strategies: An investigative study in the Omani school and university context. Asian Journal of Social Science and Humanities, III(4), 37-48.

Signes, C. G., \& Arroita, B. C. (2015). Analysing lexical density and lexical diversity in university students' written discourse. Procedia-Social and Behavioral Sciences (pp. 546-556).

Sihem, B (2013). Social responsibility of educators. International Journal of Education Research and Technology, IV(1), 46-51. Retrieved from http://www.soeagra.com/ijert/ijertmarch2013/8.p df.

Smith, R. C., Dorsey, A. A., Lyles, J. S., \& Frankel, R. M. (1999). Teaching self-awareness enhances
p-ISSN 2301-7554, e-ISSN 2541-3643

https://journal.uniku.ac.id/index.php/ERJEE

learning about patient-centered interviewing. Academic Medicine, 74(11), 1242-1249. Retrieved from http://bpsmedicine.msu.edu/pdf/22-

$\% 20 \% 20$ ctstudypstrng.pdf.

Stapa, S. H., Maasum, T. N. R. T., \& Aziz, M. S. A. (2014). Identifying problems in writing thesis introductions in research methodology class. Procedia-Social and behavioral sciences, 112, 497-502. doi: 10.1016/j.sbspro.2014.01.1194.

Stegan, O. (2003). Lexical density in oral versus written rangi texts. SOAS Working Papers in Linguistics, $X V, 173-184$.

Supriya, et al. (2018). Systematic review of literature review: Best practices. Academic Radiology. doi: 10.1016/j.acra.2018.04.025.

Thanh, N. C. (2015). The difference between spoken and written grammar in English, in comparison with Vietnamese. Gist Education and Learning Research Journal, (11), 138-153.

Vieira, D. S., Picoli, S., \& Mendes, R. S. (2018) Robustness of sentence length measures in written texts. Physica A: Statistical mechanics and its applications, 506, 749-754. doi: 10.1016/j.physa.2018.04.104.

Woo, M. M., Chu, S. K. W., \& Li, X. (2013). Peerfeedback and revision process in a wiki mediated collaborative writing. Educational technology research and development, 61(2), 279-309. doi: 10.1007/s11423-012-9285-y.

Wuest, J., et al. (2015). The process, outcomes, and challenges of feasibility studies conducted in partnership with stakeholders: A health intervention for woman survivors of intimate partner violence. Retrieved from https://onlinelibrary.wiley.com/doi/pdf/10.1002/n ur.21636.

Zhang, B. (2013). An analysis of spoken and written language and how they affect English language learning and teaching. Journal of Language Teaching and Research, IV(4), 834-838. 


\section{Saniago Dakhi \& Horas Hutabarat}

Language effectiveness and factors influencing scientific writing of Indonesian undergraduate thesis 